\title{
Debris characteristics and ice-shelf dynamics in the ablation region of the McMurdo Ice Shelf, Antarctica
}

\author{
Neil GLASSER, ${ }^{1}$ Becky GOODSELL, ${ }^{2}$ Luke COPLAND, ${ }^{3,4}$ Wendy LAWSON ${ }^{2,3}$ \\ ${ }^{1}$ Centre for Glaciology, Institute of Geography and Earth Sciences, University of Wales, Aberystwyth SY23 3DB, UK \\ E-mail: nfg@aber.ac.uk \\ ${ }^{2}$ Department of Geography, University of Canterbury, Private Bag 4800, Christchurch, New Zealand \\ ${ }^{3}$ Gateway Antarctica, University of Canterbury, Private Bag 4800, Christchurch, New Zealand \\ ${ }^{4}$ Department of Geography, University of Ottawa, Ottawa, Ontario K1N 6N5, Canada
}

\begin{abstract}
This paper presents observations and measurements of debris characteristics and ice-shelf dynamics in the ablation region of the McMurdo Ice Shelf in the Ross Sea sector of Antarctica. Ice-shelf surface processes and dynamics are inferred from a combination of sedimentological descriptions, ground-penetrating radar investigations and through ablation, velocity and ice-thickness measurements. Field data show that in the study area the ice shelf moves relatively slowly $\left(1.5-18.3 \mathrm{~m} \mathrm{a}^{-1}\right)$, has high ablation rates (43-441 $\mathrm{mm}$ during 2003/04 summer) and is thin (6-22 $\mathrm{m})$. The majority of debris on the ice shelf was originally transported into the area by a large and dynamic ice-sheet/ice-shelf system at the Last Glacial Maximum. This debris is concentrated on the ice-shelf surface and is continually redistributed by surface ablation (creating an ice-cored landscape of large debris-rich mounds), ice-shelf flow (forming medial moraines) and meltwater streams (locally reworking material and redistributing it across the ice-shelf surface). A conceptual model for supraglacial debris transport by contemporary Antarctic ice shelves is presented, which emphasizes these links between debris supply, surface ablation and ice-shelf motion. Low-velocity ice shelves such as the McMurdo Ice Shelf can maintain and sequester a debris load for thousands of years, providing a mechanism by which ice shelves can accumulate sufficient debris to contribute to sediment deposition in the oceans.
\end{abstract}

\section{INTRODUCTION}

This paper aims to provide insight into debris characteristics and ice-shelf dynamics in the ablation region of the McMurdo Ice Shelf, Antarctica, using a combination of sedimentological, ground-penetrating radar (GPR), ablation, velocity and ice-thickness data. Ice shelves comprise the floating seaward margins of polar ice sheets, fringing 45\% of the Antarctic continent. They are important in global Earth system processes for four main reasons: (i) ice shelves play a significant role in the global ice-volume-sea-level system because the calving of icebergs from their termini accounts for approximately $90 \%$ of Antarctic ice loss, often in catastrophic events (Vaughan and Doake, 1996; MacAyeal and others, 2003); (ii) ice shelves control the dynamics, and therefore the system response time, of upstream inland Antarctic ice (De Angelis and Skvarca, 2003); (iii) rapid heat exchange in sub-ice-shelf cavities has a significant impact on the global ocean heat budget (Williams and others, 2001; Joughin and Padman, 2003); and (iv) catastrophic iceberg calving events from ice shelves have been proposed as a cause of major Late Quaternary climatic perturbations (Hulbe and others, 2004).

The McMurdo Ice Shelf is unusual among Antarctic ice shelves in that it has significant surface ablation, minimal calving and large accumulations of surface debris. In this paper we (i) describe the distribution and nature of debris on the surface of the ice shelf; (ii) identify debris-transport processes on and within the ice shelf; (iii) describe the sediment-landform assemblages developed on and immediately adjacent to the ice shelf; and (iv) make inferences concerning the contemporary and former dynamics of the ice shelf. Understanding the present and historical debris-transport paths on ice shelves allows us to recognize historical and modern changes in processes which may, in turn, be a response to internal or external change. Descriptions of the sediment entrained, transported and deposited by ice shelves are also required for comparison with the offshore sedimentary record (Evans and Pudsey, 2002; Hulbe and others, 2004). For example, Hulbe and others (2004) proposed an ice-shelf mechanism for largescale sedimentation events in the North Atlantic region ('Heinrich events'), but did not elaborate on the sedimentological properties of the ice shelves leading to the ice-rafted debris record in the deep ocean. The work here sheds light on this subject.

\section{FIELD LOCATION}

The McMurdo Ice Shelf is a small ice shelf in the Ross Sea sector of Antarctica (Fig. 1a). This study focuses on two areas in the western area of the McMurdo Ice Shelf: (i) the 'Black Island medial moraine' (BIMM) that stretches from Black Island to the ice-shelf edge and (ii) Bratina Island and the surrounding area on the leading edge of the 'Swirls' (as referred to by Kellogg and others, 1990) (Fig. 1). The western part of the McMurdo Ice Shelf is dominated by surface ablation, creating numerous surface meltwater features as well as concentrating debris on the ice-shelf surface. Accentuated surface ablation is a consequence of the prevailing southwesterly winds, which are adiabatically warmed as they descend from Minna Bluff and Mount Discovery and pass across the ice surface. The McMurdo Ice Shelf supports one of the largest areas of meltwater in the Ross Sea sector of Antarctica. Each austral 

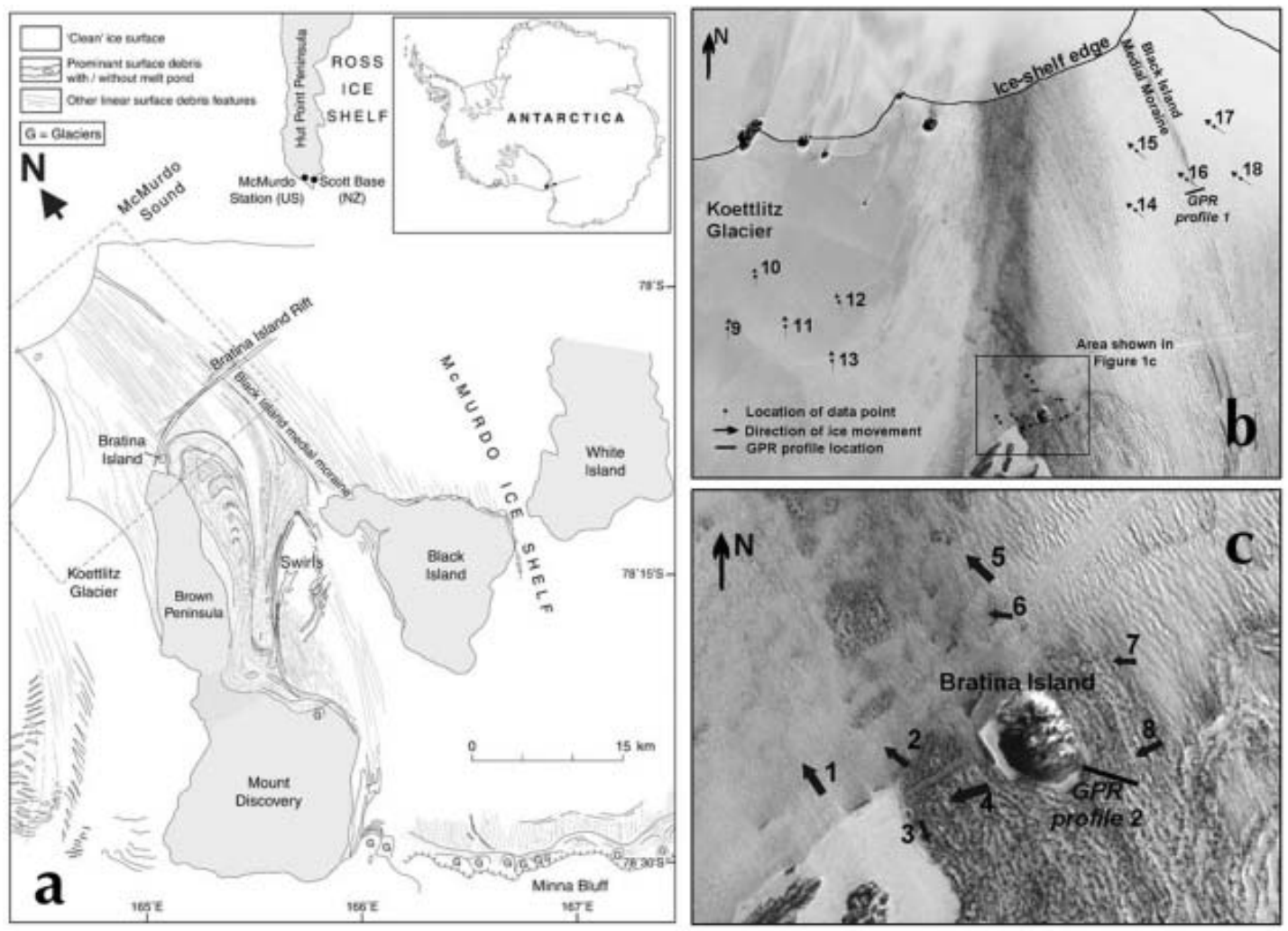

Fig. 1. (a) Overall surface structures and debris distribution on the McMurdo Ice Shelf and surrounding area mapped from ASTER imagery (from various dates between 2000 and 2003). Dashed box indicates area enlarged in Figure 1b. (b) ASTER image showing study areas, GPR profile locations and data locations. (c) Enlargement of Bratina Island area. Arrows indicate direction of ice movement. (Data for locations 1 to 18 are presented in Table 2.)

summer approximately $25 \%$ of the $1500 \mathrm{~km}^{2}$ ice shelf is covered in streams, ponds and small lakes. Meltwater varies from fresh to hypersaline and fills hollows in the highly raised surface topography amongst widespread patches and bands of marine and moraine debris (Pridmore and others, 1995). Some ponds are clear whilst others support thick mats of cyanobacteria (algal mats) (Hawes and others, 1999).

Debenham (1920) was the first to describe the debris on the McMurdo Ice Shelf, in particular the occurrence of marine biota including fish, sponges, starfish and shells. The combination of sea water and sediment freezing onto the base of the ice shelf and high surface ablation causes a net upward migration of ice and debris, allowing debris to become concentrated on the ice surface (Debenham, 1961, 1965). Subsequent work on the ice shelf's marine biota and sediments includes that of Swithinbank and others (1961), Speden (1962), Gow and others (1965), Kellogg and others (1977, 1990), Brady (1978), Hayward and Taylor (1984), Kellogg and Kellogg (1987), Hart (1990) and Wilson (2000).

The solid geology of the area immediately surrounding the McMurdo Ice Shelf is dominated by fine-grained volcanic rocks including olivine basalt, trachyte, kenyte and pyroclastic deposits that form both Black Island and Brown Peninsula (Bushell, 1970; Bradshaw, 1990). Outside the immediate catchment area of the contemporary McMurdo Ice Shelf are quartz dolerites and sandstones of the Ferrar Dolerite and Beacon Group, granites, granodiorites and diorites of the Granite Harbour Intrusives and quartzofeldspathic metasediments of the Ross Supergroup.

\section{METHODS}

Data were collected for ice-shelf surface sediments, subice surface relationships and ice depths using GPR surveys, surface ablation measurements and surface velocity measurements.

\section{Sediments}

Debris distribution on the surface of the ice shelf was mapped from Terra ASTER (Advanced Spaceborne Thermal Emission and Reflection Radiometer) imagery and aerial photography interpretation (Fig. 1a). Field observations of sediment-landform assemblages and their relationship to the ice shelf were made in January 2004 to indicate debris provenance, debris-transport history and the nature of debris modification during transport by the ice shelf. Sedimentary facies were described according to texture, particle size and clast-shape analyzes. Poorly sorted sediments were classified in the field using the Hambrey and Glasser (2003) modification of the Moncrieff (1989) classification. Clast morphology was analyzed for samples of 50 clasts, including clast roundness on a modified Powers (1953) scale and the measurement of $a, b$ and $c$ axes for clast shape. These data were analyzed using the approach of Benn and Ballantyne (1994), in which the RA index (\% of angular and very angular clasts) is plotted against the C40 index (\% of clasts with $c / a$ axial ratio $\leq 0.4$ ) on a covariant plot. This method has been shown to provide good discrimination between glacial facies in high-latitude environments (Bennett and others, 1997). Clast lithological analyzis is based on field identification of hand specimens. 
Table 1. Sediment-landform assemblages on the McMurdo Ice Shelf and adjacent land surfaces. SA: sub-angular; SR: sub-rounded

Sediment-landform assemblage

1. Medial moraines

Linear chains of debris composed of ice-cored cones and ridges. Overall length of chains up to $\sim 20 \mathrm{~km}$, with average width of $\sim 100 \mathrm{~m}$. Individual cones and ridges $\sim 2 \mathrm{~m}$ high and $\sim 4 \mathrm{~m}$ diameter with intervening meltwater ponds and streams.

2. Isolated sand and gravel patches Thin, isolated patches (typically 1-10 m diameter) of well-sorted sand and gravel on the ice-shelf surface. Sand and gravel patches commonly found alongside frozen or liquid meltwater ponds.

3. Sub-horizontal curvilinear moraines Sub-horizontal curvilinear moraines $\sim 4 \mathrm{~m}$ high and $\sim 5 \mathrm{~m}$ wide, wrapped around the lower slopes of land masses adjacent to the contemporary McMurdo Ice Shelf.

4. Ice-cored ridges and cones

Chaotic collection of ice-cored cones and ridges on the ice-shelf surface. Individual cones and ridges separated by meltwater ponds.
Thin ( $\sim 0.1 \mathrm{~m})$ layer of sandy gravel, sandy pebble-gravel, sandy cobble-gravel or diamicton. SA and SR clasts dominate. Mixed clast lithologies.

Well-sorted sand and granule gravel. SA and SR clasts dominate. Mixed clast lithologies.

Predominantly sandy gravel. Mixed clast lithologies with high exotic granite content (30-40\%). Occasional ventifacted clasts. Shells and shell fragments common.

Thin ( $\sim 0.1 \mathrm{~m})$ layer of sandy gravel, gravelly sand, sandy pebble-gravel or diamicton. SA and SR clasts dominate. Mixed clast lithologies. Scattered fossil shells and contemporary faunal remains.
Sediments overlie clean, bubble-poor grey ice.

Ice-cored medial moraine related to contemporary flow of the McMurdo Ice Shelf.
Sediments either overlie or are sandwiched between clean, bubble-poor grey ice.

Moraines occur on the flanks of land masses at elevations above contemporary McMurdo Ice Shelf. No buried ice observed in moraines, but overall morphology indicates buried ice may be present at depth.

Debris on surface overlies clean, bubble-poor grey ice. Sandwiching of sediment between ice layers.
Material reworked from the ice-cored medial moraine and redeposited by ice-shelf surface meltwater streams and meltwater ponds.

Ice-shelf moraines formed between the McMurdo Ice Shelf and adjacent land during Holocene ice-shelf recession.

Downwasting of debris on contemporary McMurdo Ice Shelf surface. Debris originally transported into the area by a larger and more dynamically active ice-sheet/ice-shelf system.

\section{Radar data}

Subsurface sediment-structure relationships and ice depths were analyzed using GPR data collected during November and December 2003, using a Sensors and Software Inc. pulseEKKO 100 GPR system with $100 \mathrm{MHz}$ antennae. Data were collected using the 'stop and collect' constant-offset technique, in which antennae were fixed $1 \mathrm{~m}$ apart and data collected using a $0.25 \mathrm{~m}$ step size. Antennae were orientated at right angles to the direction of data collection, and each trace is the average of 32 stacks. Post-processing and migration of the profiles was carried out using Win EKKO software supplied by Sensors and Software Inc. The final profiles were plotted with Kingdom Suite by Seismic MicroTechnology Inc. A high-pass filter was applied to remove the decaying transient component at the start of the trace (i.e. dewow), and a bandpass filter was applied to remove noise. Automatic gain control was also applied. A radio-wave velocity (RWV) of $0.1783 \mathrm{~m} \mathrm{~ns}^{-1}$, derived from central midpoint surveys, was used to convert two-way travel time to depth. The GPR measurements were all made at locations in the ablation zone with exposed ice at the surface, so no correction was made for the presence of firn that may cause spatially variable RWVs in the accumulation area. Thickness measurements with the pulseEKKO system are estimated to be accurate to $\pm 0.25 \mathrm{~m}$.

Point measurements of ice thickness were also made at locations 7 and 17 (Fig. 1) with a monopulse radar transmitter based on the design of Narod and Clarke
(1994), and manufactured by Icefield Instruments Inc. This was operated at a centre frequency of $10 \mathrm{MHz}$, with the antennae parallel to each other ( $\mathrm{H}$-plane) and separated by a horizontal distance of $10 \mathrm{~m}$. The received traces were recorded with an airwave-triggered Tektronix $720 \mathrm{~A}$ digital oscilloscope connected to a palmtop computer. Accuracy of this measurement is estimated to be $\pm 1.7 \mathrm{~m}$. The location and topography of these points and the GPR profiles were calculated from post-processed global positioning system (GPS) measurements.

\section{Ablation}

Surface ablation was measured in the field by repeat measurements of PVC poles inserted $1 \mathrm{~m}$ into the ice shelf at eight exposed ice locations across the study area (Fig. 1a). The poles were established in November 2003 with a Kovacs ice drill, and remeasured in December 2003 and January 2004. The measurement period includes all but three positive degree-days during the 2003/04 summer season, as measured by an automatic weather station located on the ice shelf approximately $250 \mathrm{~m}$ southeast of Bratina Island. To calculate water equivalents, ablation measurements are multiplied by 0.917 , the average density $\left(\mathrm{g} \mathrm{cm}^{-3}\right)$ of solid ice.

\section{Velocity}

Surface velocities were measured by recording repeat positions of 18 PVC poles (Fig. 1b and c) with a surveygrade Trimble 4700 GPS receiver in summer 2003/04 and 

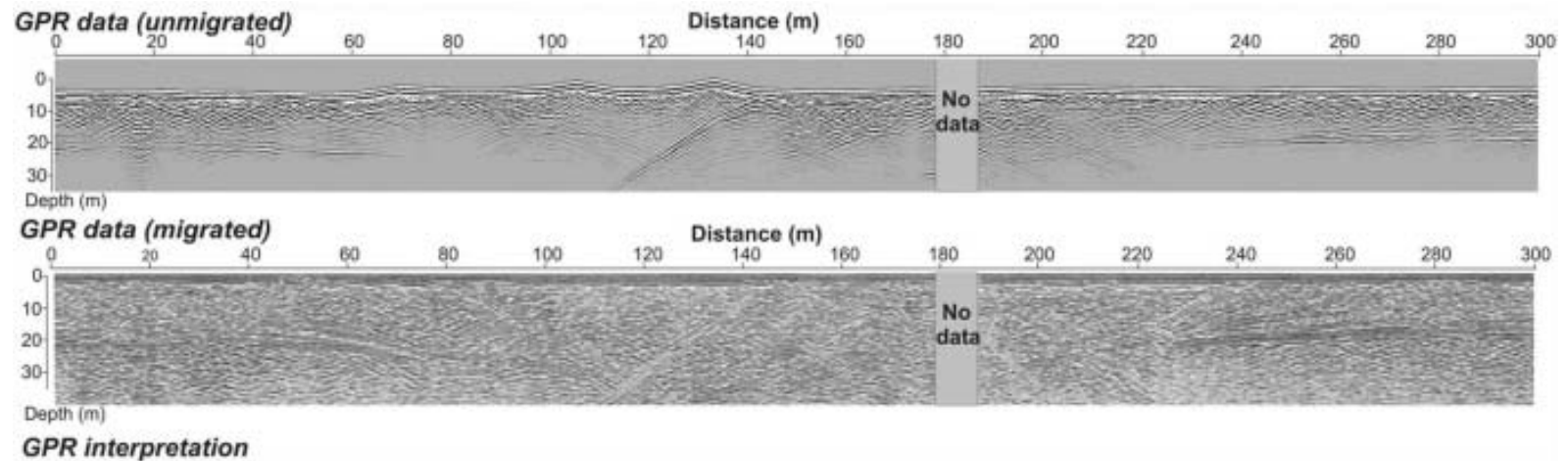

GPR interpretation

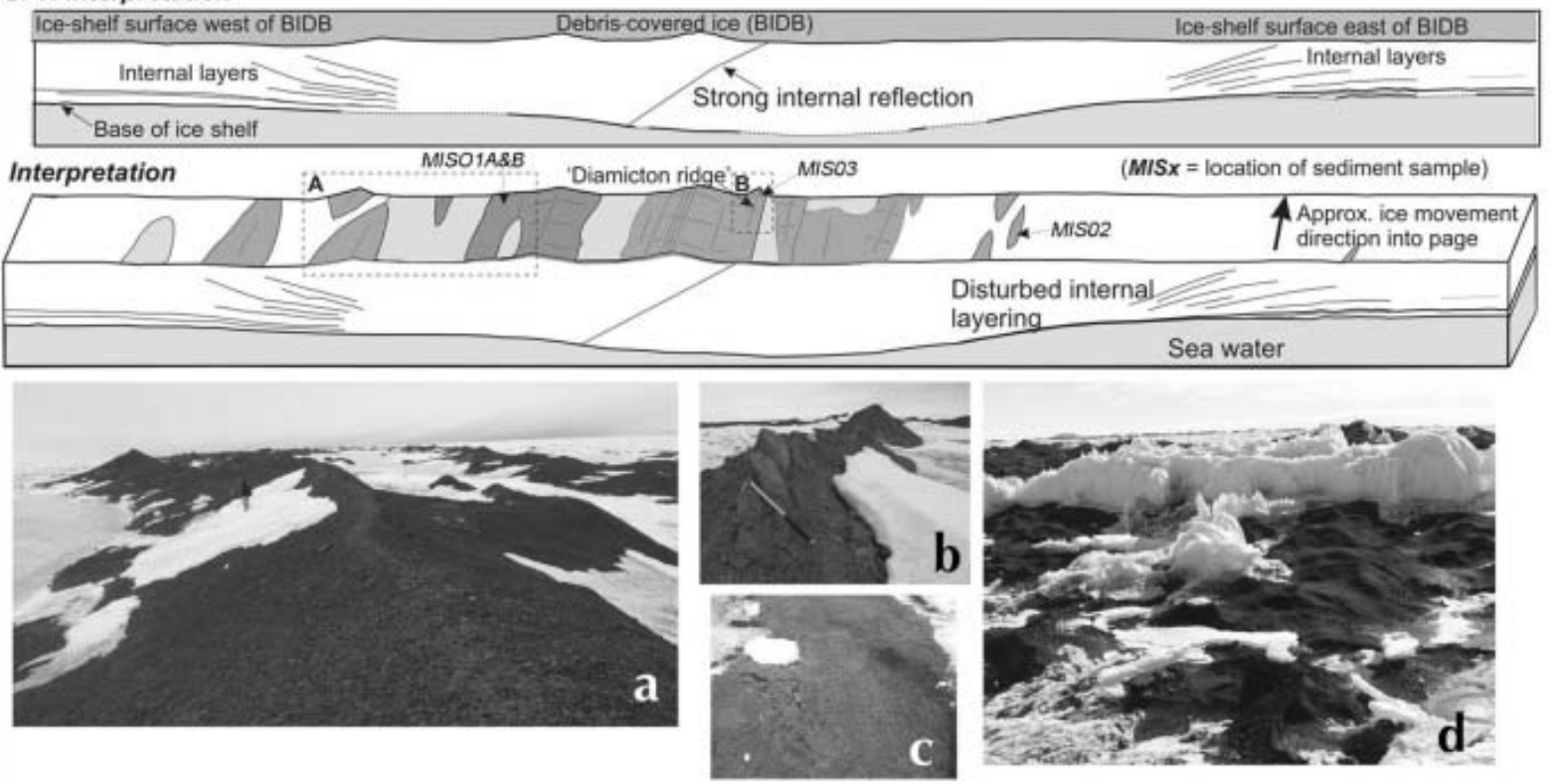

Fig. 2. GPR profile from across BIMM, with interpretation and photographs of associated lithofacies in the BIMM sediment-landform assemblages. The GPR profile is presented as both unmigrated and migrated data. Photographs of sediments show: (a) Sandy gravel on $\sim 5 \mathrm{~m}$ high ice-cored debris cone. Figure on snowpatch indicates scale. (b) Clast-rich sandy diamicton forming $\sim 1 \mathrm{~m}$ high debris ridge. Ice axe gives scale. (c) Thin $(\sim 50 \mathrm{~mm})$ cover of sand and granule gravel overlying bare ice. Pen gives scale. (d) Patches of well-sorted sand on the ice-shelf surface immediately adjacent to BIMM. The sand was deposited by a large surface meltwater stream flowing to the left of the photograph. Image is $\sim 2 \mathrm{~m}$ across.

summer 2004/05 (i.e. over a period of 296-358 days). The GPS receiver was run for at least $30 \mathrm{~min}$ at each stake on each visit, and the data were differentially corrected using a temporary GPS base station on Bratina Island and the permanent base station at McMurdo (MCM4). Errors are estimated at $<30 \mathrm{~mm}$ in the horizontal direction. Velocities were also calculated over shorter periods during the summer, but are not displayed here as there was no significant temporal variability in surface motion, and the errors are reduced with the longer period between measurements.

\section{RESULTS}

Four main sediment-landform assemblages were identified in the study area (Table 1).

\section{Black island medial moraine area}

Sediment-landform assemblage 1: the Black Island medial moraine (BIMM)

Description: The BIMM comprises a linear chain of large ( $\sim 5 \mathrm{~m}$ high) ice-cored debris cones and ridges separated by intervening meltwater ponds. Individual debris cones and ridges are texturally variable but are typically composed of sandy gravel, sandy pebble-gravel or sandy cobble-gravel (Fig. 2). Gravel-sized clasts in these facies are predominantly sub-angular and sub-rounded with occasional angular and rounded clasts, of mixed lithology (although dominated by locally derived fine-grained volcanics) and do not bear striations or facets (Figs 3 and 4). A clast-rich sandy diamicton occurs within the middle of the moraine, forming a ridge $\sim 200 \mathrm{~m}$ long and $\sim 3 \mathrm{~m}$ wide (Fig. 2b). Gravel-sized clasts in the diamicton are angular, sub-angular and subrounded, of mixed lithology with occasional (6\%) faceted clasts (Fig. 3). Striated boulders were also observed in the diamicton. The remains of numerous marine fauna are found in this moraine, including fish (Trematomus hansoni), bryozoan (Hornera sp.) sponges (Cinachyra antarctica), starfish (Echinodermata) and shells (Antarctic barnacle and Antarctic scallop A. colbecki). Field observations indicate that sediment in and around the BIMM sits directly on clean debris-free ice on the ice-shelf surface (Fig. 2c and d).

Interpretation: The degree of sorting of sediments in the BIMM indicates that this material has undergone active glacial transport. The presence of high percentages of sub-angular and sub-rounded clasts, together with striated and faceted clasts in the diamicton indicates material 

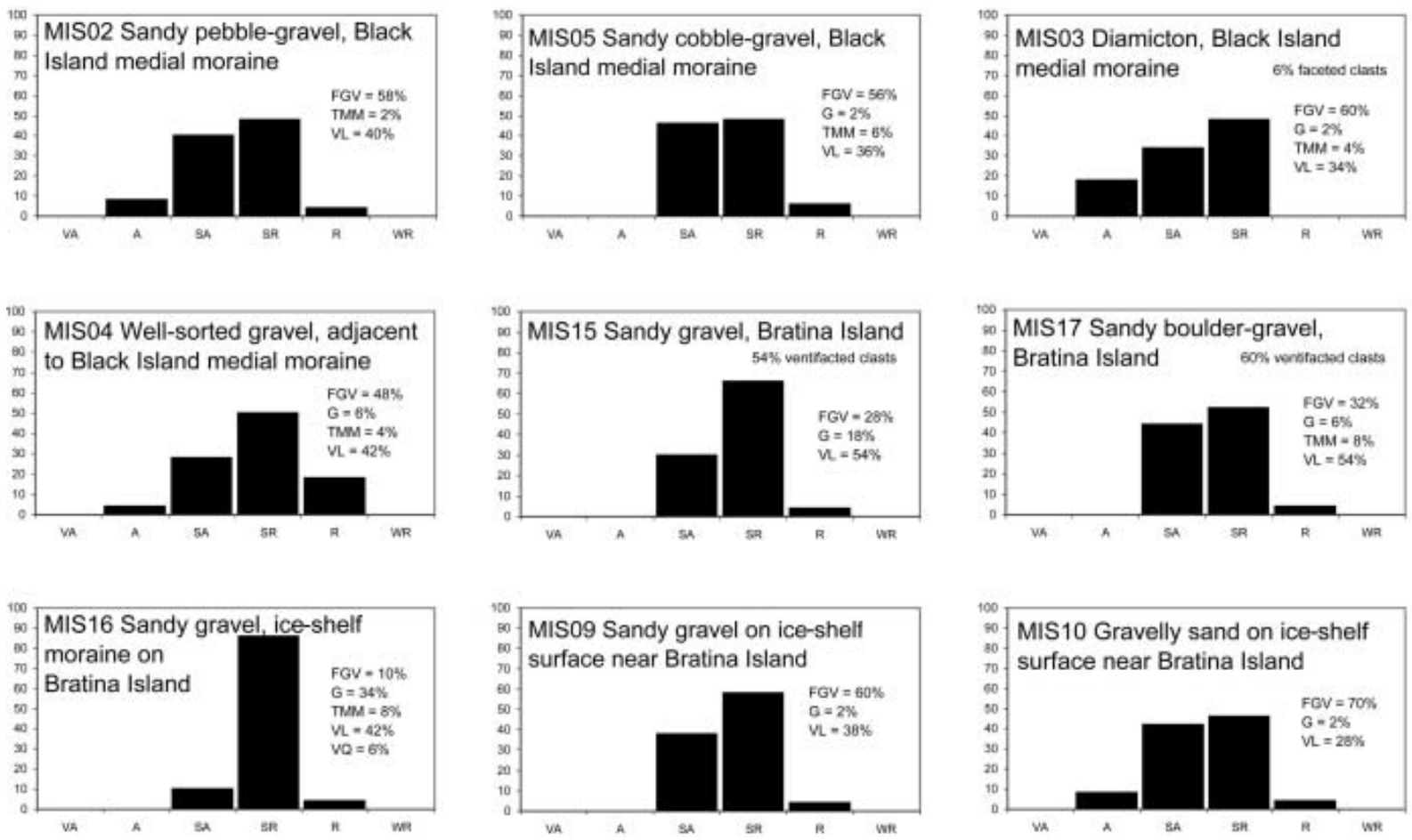

Fig. 3. Clast roundness histograms (modified Powers roundness) for lithofacies on the BIMM, Bratina Island and the surface of the McMurdo Ice Shelf. Roundness categories are VA - very angular, A - angular, SA - sub-angular, SR - sub-rounded, $\mathrm{R}$ - rounded and WR - well rounded. Lithology categories are: FGV - fine-grained volcanics, G - granite, TMM - Transantarctic Mountains metasediments, VL - vesicular lava, VQ - vein quartz. Approximate locations of samples are noted on Figures 2 and 6.

originally modified by crushing and abrasion during transport at the ice/bed interface (Boulton, 1978) or along the side-walls of tributary valleys and nunataks (Evans and Cofaigh, 2003). The presence of marine faunal remains in the moraine also indicates a basal origin.

Our preferred interpretation of the origin of this feature is that it represents basally derived supraglacial material forming a medial moraine. The orientation of the medial moraine differs slightly from the orientation of measured surface velocities, suggesting that this feature may be a former flow-unit boundary which is now being slowly reorientated under the contemporary flow regime. This material probably appears on the ice surface as a result of the high surface ablation rates on the ice shelf (see below) and possibly also as a result of upward flowlines in the flow confluence around Black Island (cf. Gomez and Small, 1985). This interpretation fits with the published ${ }^{14} \mathrm{C}$ dates of Kellogg and others (1990), which indicate that marine shells in the debris increase in age with distance from Black Island. Kellogg and others (1990) argued that the progression in age of the shells along the BIMM traces the retreat of the iceshelf grounding line through Holocene times, although the progression of dates could equally be interpreted as dating the time when fauna were entrained from shore debris on Black Island.

\section{Sediment-landform assemblage 2: isolated gravel patches}

Description: Thin isolated patches of well-sorted sand and granule gravel are present on the ice-shelf surface either side of the BIMM (Fig. 2d). This thin debris creates a low-relief $(<1 \mathrm{~m}$ relative relief) landscape of ice-cored cones and ridges, separated by small (generally metre-scale) meltwater streams and ponds. In places, patches of gravel can be observed on the banks of active meltstreams. Gravel-sized clasts are sub-angular, sub-rounded and rounded, of mixed lithology (although dominated by locally derived finegrained volcanics) and do not bear striations or facets (Figs 3 and 4). There is a general decrease in quantities of surface debris with increasing distance from the medial moraine.

Interpretation: This sediment-landform assemblage is interpreted as the product of small-scale reworking and redistribution by supraglacial streams and meltwater ponds of the debris in the larger BIMM. Reworking of material by supraglacial streams is a common process operating on glaciers where sufficient meltwater is released on the ice surface (Glasser and others, 1999). This interpretation is supported by (i) field observations of supraglacial meltwater streams eroding and transporting this material, (ii) the similarities in clast morphology and lithology between this lithofacies and the sand and gravel facies in the BIMM (Figs 3 and 4) and (iii) observations of this process in operation on Antarctic ice shelves and adjacent ice-free areas where liquid lakes are capped by a permanent floating ice cover (Hendy and others, 2000).

\section{Topographic and subsurface relationships: GPR} profile 1 (Fig. 2)

GPR profile 1 was collected perpendicular to ice flow, across the BIMM (Fig. 1b). GPR surveying along GPR profile 1 indicates that the ice surface is approximately $0.8 \mathrm{~m}$ greater in elevation to the east of the BIMM than the west. This does not reflect a difference in ice thickness either side of the BIMM. Within the ice there are flat-lying, continuous basal reflectors to the east $(0-70 \mathrm{~m})$ and west $(195-300 \mathrm{~m})$ 


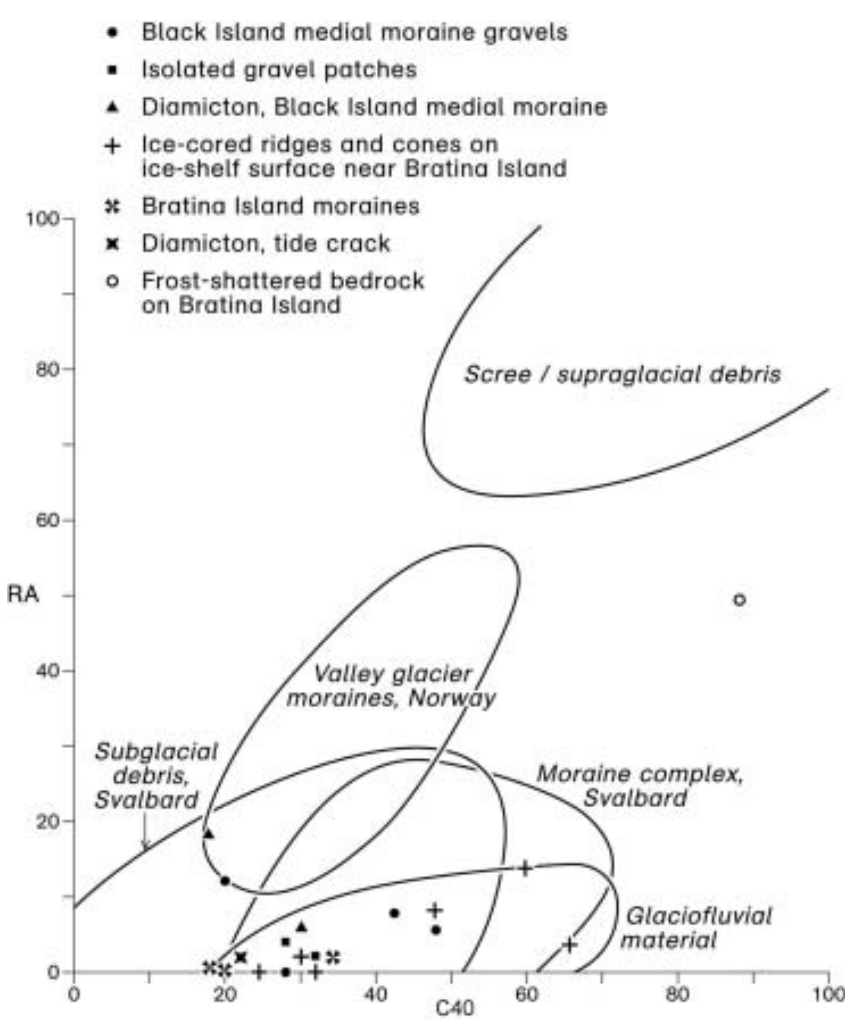

Fig. 4. Covariant plot of the RA index (\% of angular and very angular clasts) against the $\mathrm{C} 40$ index (\% of clasts with $c / a$ axial ratio $\leq 0.4)$ for lithofacies on and around the McMurdo Ice Shelf. Each symbol represents a sample of 50 clasts. The facies envelopes are based on data presented by Benn and Ballantyne (1994) and Bennett and others (1997). The moraine complex envelope contains 44 samples of clasts in diamicton emplaced on land by the 1948 surge or rapid advance of the Kongsvegen/Kronebreen tidewater glacier in Svalbard (Bennett and others, 1999).

along the profile. Between the surface and the basal reflections, there are multiple hyperbolae, particularly between 140 and $210 \mathrm{~m}$. No data were collected from between 178 and $187 \mathrm{~m}$ because this area was covered by a melted meltwater pond. There is a strong reflector dipping to the west, visible between 110 and $145 \mathrm{~m}$.

Interpretation: The BIMM marks the boundary of ice sourced either side of Black Island. The presence of a large internal, dipping reflector, which coincides with a diamicton ridge at the ice-shelf surface, may indicate that deformation is still occurring at this boundary; the fact that the ice-shelf surface is higher to the east than to the west supports this hypothesis. The thickening of ice under the moraine could be the result of (i) sediment cover protecting the ice underneath the moraine from ablation, (ii) thickening of ice in response to tectonic processes or (iii) a combination of the two.

\section{Bratina Island area}

\section{Sediment-landform assemblage 3: Bratina Island moraines}

Description: Wrapped around the lower slopes of Bratina Island moraine is a group of large sub-horizontal curvilinear moraines (Fig. 5). The moraines are continuous over distances of $>2 \mathrm{~km}$. Nearest the contemporary McMurdo Ice Shelf they are $2-10 \mathrm{~m}$ in height, with a single sharp crest.

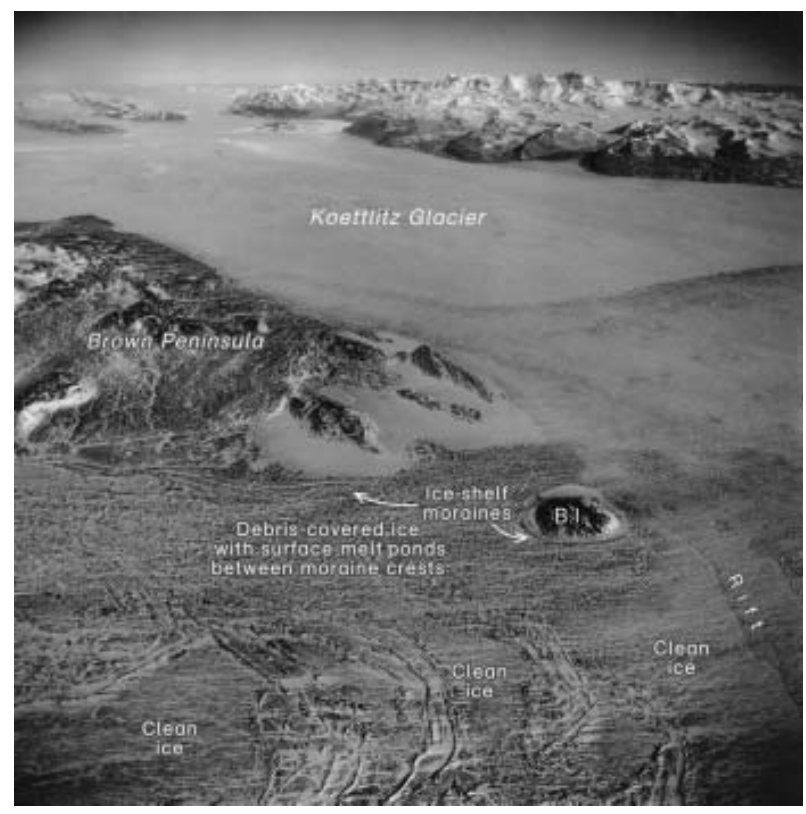

Fig. 5. Oblique aerial photograph of Bratina Island (B.I.) showing ice-cored ridges and cones of debris on the contemporary ice-shelf surface, ice-shelf moraines and clean ice areas.

Higher on the island the ridges are lower $(\sim 5 \mathrm{~m}$ in height $)$ and more subdued. Individual ridges vary in their composition, but the majority are composed of sandy gravel. Gravel-sized clasts in the sandy gravel are mainly subrounded with occasional sub-angular and rounded clasts, of mixed lithology and do not bear striations or facets (Figs 3 and 4). The moraines are notable for their high proportion of exotic pink and white granite clasts (typically $30-40 \%$ in samples of 50) which give these deposits a distinctive colour. Shells and shell fragments are also common. Below the elevation of the moraines, Bratina Island is separated from the contemporary McMurdo Ice Shelf by a tide crack varying in width from $\sim 2$ to $15 \mathrm{~m}$, along which is exposed a clast-poor to clast-rich muddy diamicton containing subrounded and sub-angular clasts of mixed lithology (Fig. 6). No striated and faceted clasts occur in this lithofacies, which is generally capped by a thin (millimetre-scale) white salt crust.

Interpretation: Sub-horizontal single- or multiple-crested ridges of variable composition (ranging from coarse angular debris to muddy diamicton) have been described from the George VI Sound on the Antarctic Peninsula, where they were interpreted as ice-shelf moraines (Sugden and Clapperton, 1981). The Bratina Island moraines are interpreted here as accumulations of sediment formed where the contemporary (but vertically more extensive) McMurdo Ice Shelf abuts the land. The sharp-crested ridges probably retain an ice core, whereas the subdued ridges represent a later stage in the degradation of the ice cores. The Bratina Island moraines are very close in elevation (within 15-20 m) to the surface height of the contemporary ice shelf, suggesting that they were formed relatively recently (probably within the last century). The diamicton exposed in the tide cracks is interpreted as material elevated by upwardly directed flowlines, in response either to the high surface ablation rates or to longitudinal shortening where the ice shelf meets the topographic barrier created by Bratina Island. 

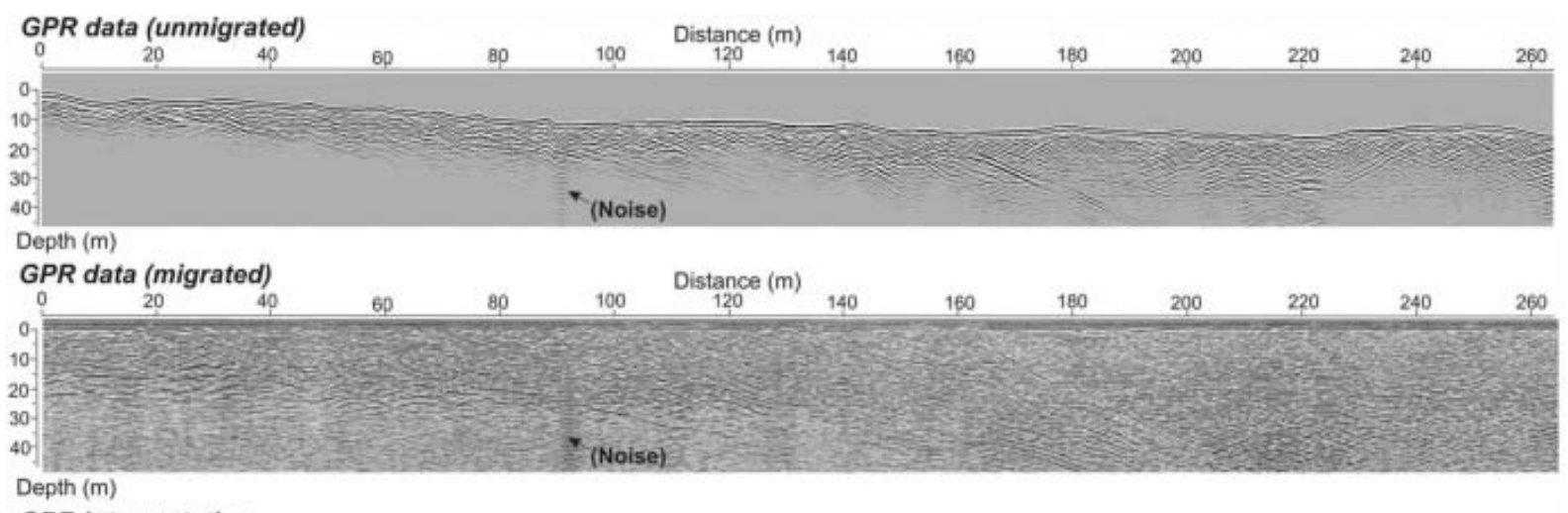

\section{GPR interpretation}
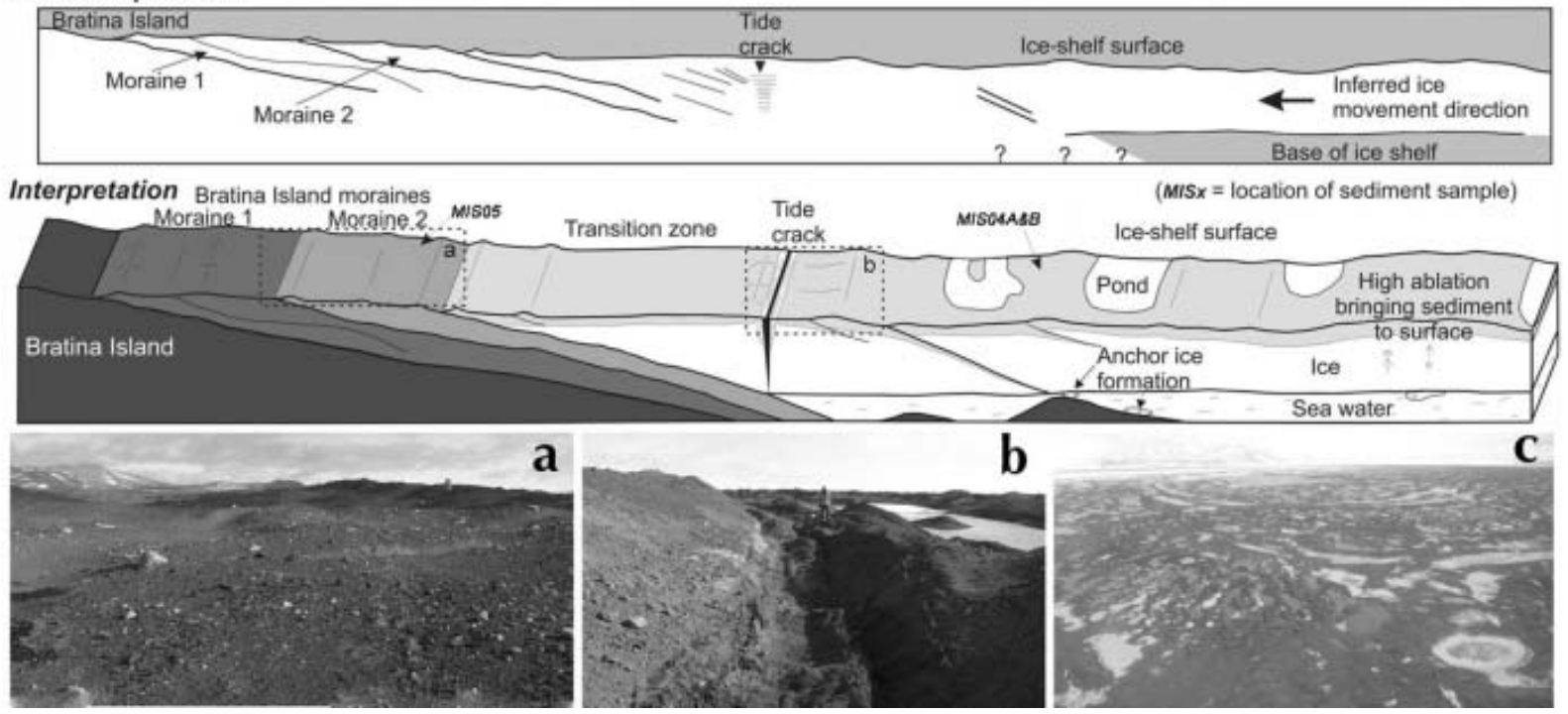

Fig. 6. GPR profile from Bratina Island out onto ice shelf, interpretation and photographs of associated lithofacies and sediment-landform assemblages. The GPR profile is presented as both unmigrated and migrated data. Sediments show: (a) Bratina Island moraines. Figure (top right) gives scale. (b) Tide crack between the ice shelf and Bratina Island. Figure (top centre) gives scale. (c) Aerial view of ice-cored ridges and cones on the surface of the ice shelf.

\section{Sediment-landform assemblage 4: ice-cored ridges and cones}

Description: The ice-cored ridges and cones surrounding Bratina Island are individual mounds of sandy gravel, gravelly sand, sandy pebble-gravel or diamicton (Figs 6 and 7), often containing scattered fossil marine shells and contemporary faunal remains. Individual mounds are separated by large $(100 \mathrm{~m}$ scale) meltwater ponds. Active failures and exposures in the walls of the mounds reveal bare ice beneath and show that the ice-shelf surface sediments are generally thin $(\sim 0.1 \mathrm{~m})$, attaining a maximum thickness of $0.5 \mathrm{~m}$. Debris on the ice-shelf surface rests directly on clean debris-free ice, and sandwiching of sediment between ice layers is common (Fig. 7a and b). Gravel-sized clasts are predominantly sub-angular and subrounded with occasional angular and rounded clasts, of mixed lithology (although dominated by fine-grained volcanics), and do not bear striations or facets (Figs 3 and 4).

Interpretation: There is no obvious source area for the large volumes of supraglacial material present on the contemporary ice-shelf surface. The clast roundness and lithology (including the presence of Transantarctic Mountain metasedimentary rocks) indicates that this material originated outside the current extent of the ice shelf and cannot be accounted for simply by rockfall onto the ice-shelf surface in the local area. We therefore suggest that this material was transported into the McMurdo Sound area by a larger and more dynamically active ice sheet or ice shelf. Individual ridges and cones may be inherited from pre-existing glaciological structures; differential ablation concentrates debris on the ice surface. The large-scale patterns of debris distribution, visible on satellite images and aerial photography (e.g. Figs 1 and 5), strongly suggest that the ridges and cones are attributable to ice-deformation processes, which are now being affected by ablation processes.

This debris may therefore represent material originally subglacial or englacial in origin, which has been elevated to the ice surface by ice-deformation processes (e.g. longitudinal and transverse shortening) where the ice flowed into this topographic embayment. Evidence for this statement includes the nature of the folds visible on the ice-shelf surface from aerial photography and satellite imagery, which shows tight to isoclinal folds, with large parasitic folds still attached to their limbs. Some smaller-scale folds (e.g. those within the Swirls) are no longer attached to their limbs and hence are rootless. Isolated chevron folds also occur outside the Swirls area. The simplest explanation for these folds is that they represent debris bands that were originally continuous, forming approximately linear features that have been deformed by ice flowing generally northward between 

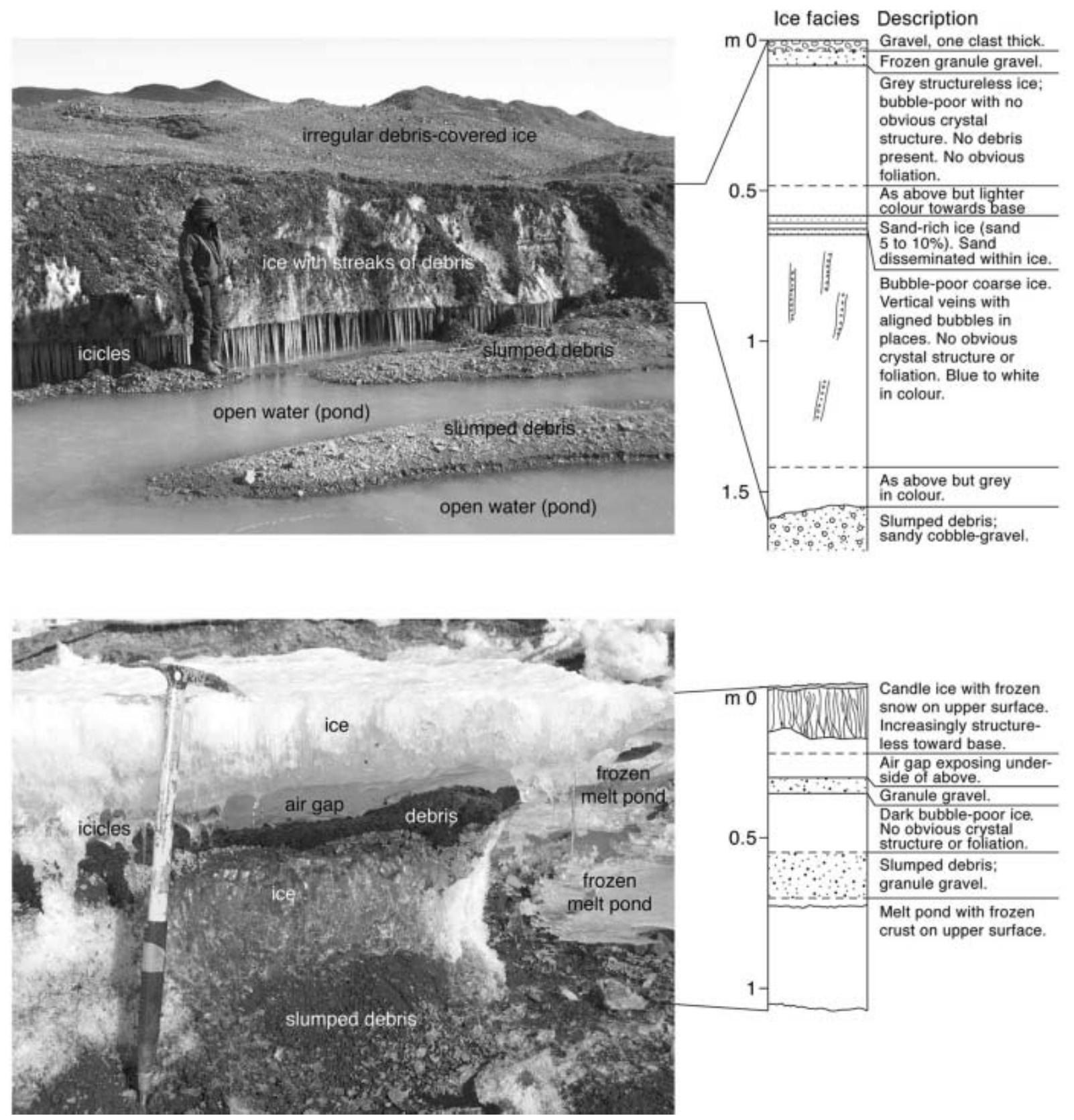

Fig. 7. Field photographs and graphic logs illustrating the nature of ice-debris relationships on the McMurdo Ice Shelf. (a) Exposure of iceshelf ice with thin cover of gravel and showing evidence of contemporary downwasting. (b) Refrozen meltwater pond showing small-scale reworking of sediments on the ice-shelf surface.

Black Island and Brown Peninsula but at several different internal velocities. Clast roundness and clast surface feature data also indicate basal transport. This material is effectively stranded on the surface of the contemporary McMurdo Ice Shelf, becoming increasingly concentrated on the ice-shelf surface through time by surface ablation.

To summarize, the ice-cored ridges and cones on the iceshelf surface are interpreted as downwasting debris originally transported into the area by a larger and more dynamically active ice sheet or ice shelf. Carbon-14 dates of biotic remains in this debris and $\delta^{18} \mathrm{O}$ values of surface ice indicate that some of the debris has been present on the ice surface since around $20 \mathrm{kyr}$ BP (Kellogg and others, 1990). The presence of contemporary corals and sponges suggests that sediment is also being continually fed to the ice-shelf surface wherever the underlying seabed is shallow enough that anchor ice is forming and attaching to the base of the ice shelf. Thus, even under contemporary flow regimes, sediment is added to the ice shelf.

\section{Topographic and subsurface relationships: GPR profile 2}

Profile 2 (Fig. 6) was collected from the southeastern side of Bratina Island. It is $263 \mathrm{~m}$ long and orientated parallel to flow. It begins on the sandy gravel/sandy boulder gravel on Bratina Island, crosses two distinct moraines on the lower slopes of the island, and then extends across ice-cored ridges and cones on the surface of the contemporary ice shelf. The profile is dominated by internal reflections and hyperbolae. Reflections become deeper with distance from Bratina Island. Deep reflections at $\sim 91-93 \mathrm{~m}$ and $220-225 \mathrm{~m}$ along the profile are noise caused by surface 
Table 2. Stake coordinates, surface velocity, ice depth and ablation data from the western part of the McMurdo Ice Shelf. Blank cells indicate data not available. See Figure 1 for stake locations

\begin{tabular}{|c|c|c|c|c|c|c|c|}
\hline \multirow[t]{2}{*}{ Location } & Northing & Easting & Velocity & $\begin{array}{l}\text { Velocity } \\
\text { direction }\end{array}$ & $\begin{array}{l}\text { Measurement } \\
\text { period }\end{array}$ & Ice depth & $\begin{array}{c}\text { Summer 2003/04 } \\
\text { ablation }\end{array}$ \\
\hline & UTM $58 \mathrm{~S}$ & UTM 58S & $\mathrm{ma}^{-1}$ & $\circ$ & & $\mathrm{m}$ & mm w.e. \\
\hline 1 & 1340119 & 0510841 & 9.4 & 326 & Jan 04-Nov 04 & & 174 \\
\hline 2 & 1340340 & 0511660 & 7.4 & 308 & Jan $04-$ Nov 04 & & \\
\hline 3 & 1339597 & 0511939 & 1.5 & 159 & Jan $04-$ Nov 04 & & \\
\hline 4 & 1339967 & 0512375 & 15.8 & 251 & Dec 03-Nov 04 & & 143 \\
\hline 5 & 1342207 & 0512476 & 10.6 & 314 & Jan 04-Nov 04 & & 257 \\
\hline 6 & 1341733 & 0512691 & 3.7 & 277 & Jan $04-$ Nov 04 & $10-11$ & 196 \\
\hline 7 & 1341278 & 0513910 & 3.1 & 272 & Jan $04-$ Nov 04 & 18 & \\
\hline 8 & 1340409 & 0514153 & 6.5 & 243 & Nov $03-$ Nov 04 & & 441 \\
\hline 9 & 1344893 & 0497098 & 11.2 & 4 & Jan 04-Nov 04 & & \\
\hline 10 & 1347514 & 0498499 & 7.8 & 352 & Jan $04-\operatorname{Nov} 04$ & & \\
\hline 11 & 1344964 & 0500023 & 9.6 & 358 & Jan $04-$ Nov 04 & 6 & 47 \\
\hline 12 & 1346229 & 0502711 & 7.9 & 340 & Jan 04-Nov 04 & & \\
\hline 13 & 1343244 & 0502356 & 9.3 & 356 & Jan $04-\operatorname{Nov} 04$ & & \\
\hline 14 & 1350872 & 0517687 & 15.5 & 311 & Nov $03-$ Nov 04 & & \\
\hline 15 & 1353878 & 0517747 & 16.1 & 312 & Nov $03-$ Nov 04 & & \\
\hline 16 & 1352423 & 0520263 & 16.7 & 305 & Jan 04-Nov 04 & $14-22$ & 127 \\
\hline 17 & 1355114 & 0521632 & 17.3 & 305 & Jan $04-$ Nov 04 & 15 & 43 \\
\hline 18 & 1352487 & 0522973 & 18.3 & 304 & Jan $04-$ Nov 04 & & \\
\hline
\end{tabular}

instruments. There are two strong shallow-dipping reflections where the profile leaves Bratina Island, which correspond to the two moraines. There is no dominant, strong basal reflector for most of the profile; instead internal reflections fade out. However, a semi-continuous flat-lying reflector at $\sim 35 \mathrm{~m}$ depth does exist from $\sim 175$ to $250 \mathrm{~m}$ along the profile. There is an abnormal zone of noise at $125 \mathrm{~m}$ along the profile, where multiple flat-lying, smallscale reflections can be seen, which coincides with a tide crack on the ice-shelf surface.

Interpretation: GPR profile 2 illustrates the nature of the transition from Bratina Island and the ice-shelf moraines on its lower slopes, across the tide crack onto the floating ice shelf. The ice shelf is about $35 \mathrm{~m}$ thick beyond the tide crack. The presence of salt associated with the tide crack caused a high dielectric contrast, resulting in the abnormal zone of noise at $125 \mathrm{~m}$ along the profile.

\section{Ablation, velocity and ice thickness in the western McMurdo Ice Shelf}

The results of the ablation measurements are shown in Table 2. Between 43 and $441 \mathrm{~mm}$ w.e. of ablation was measured in this area of the McMurdo Ice Shelf during the 2003/04 summer field season. Ablation is highest in the area around Bratina Island. Ablation rates vary according to the albedo of the surrounding ice; for example location 16 is within a debris-covered moraine and has nearly three times more ablation than the adjacent location 17, which is positioned on debris-free ice. Measurement points near Bratina Island (locations 1-8), which are situated on or near to debris-covered ice, have the highest ablation rates. Surface melt was accommodated by surface streams, which were observed to drain into tide cracks (Bratina Island) or flow in a northerly direction towards the ice-shelf edge (BIMM area).

There is a general northward movement of ice towards the seaward margin of the ice shelf, with the lowest velocities measured around Bratina Island (Table 2). Velocities measured on this part of the ice shelf are far lower than velocities recorded on other Antarctic ice shelves such as the Larsen Ice Shelf (Rack and others, 2000) and the FilchnerRonne Ice Shelf (Rignot and MacAyeal, 1998). Ice thicknesses measured range from 6 to $22 \mathrm{~m}$ (Table 2).

Interpretation: Ablation rates in this area reflect local variations in albedo, which are primarily a function of debris cover. Ice within debris-covered areas has a higher ablation rate than debris-free ice. In addition, the large amount of debris-covered ice around Bratina Island, and the albedo of Bratina Island itself may create a local microclimate. For example, a comparison of temperature data collected on debris-covered ice near Bratina Island with those recorded by an automatic weather station at Pegasus South ( $24 \mathrm{~km}$ away near Pegasus Runway, positioned on permanently snow-covered ice shelf) revealed that temperatures were, on average, $1.7^{\circ} \mathrm{C}$ warmer near Bratina Island during the 2003/04 summer. As demonstrated at location 4, localized ice collapse and calving into surface melt ponds also plays a role in the net loss of ice in this area. Ablation measured on the McMurdo Ice Shelf is high when compared to the $109 \mathrm{~mm}$ w.e. $\mathrm{a}^{-1}$ calculated for Larsen Ice Shelf at Larsen AP meteorological station $\left(66.9^{\circ} \mathrm{S}\right)$ by Shepherd and others (2003).

The presence of large meltwater streams on the surface of the ice shelf supports these ablation data. Large meltwater streams attributed to high melt rates on ice shelves have previously only been described from the Antarctic Peninsula (e.g. Mercer, 1978; Rott and others, 1998; Scambos and others, 2000).

\section{DISCUSSION}

\section{A conceptual model for supraglacial ice-shelf transport}

The distribution of landforms and sediments on the ice shelf and adjacent land masses can be used to propose a 


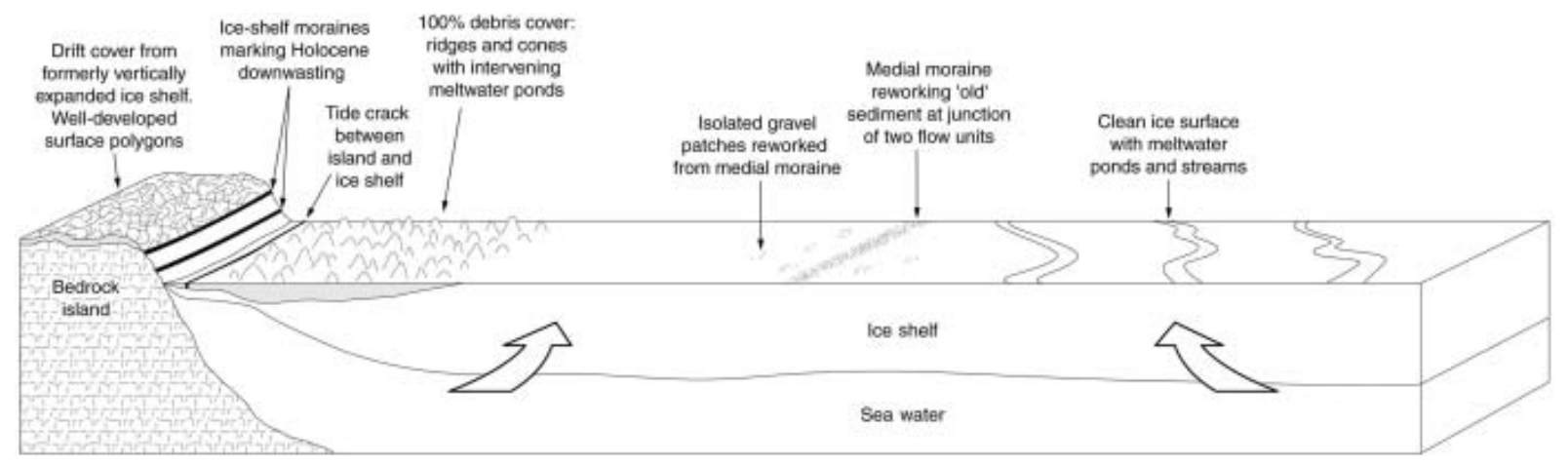

Fig. 8. Schematic cross-section through the ice shelf, indicating processes responsible for debris transport and deposition.

conceptual model of debris transport and deposition for the McMurdo Ice Shelf (Fig. 8). Land surfaces surrounding the ice shelf are mantled with deposits containing abundant erratic material, which relate to a vertically and horizontally expanded ice-sheet/ice-shelf system at the Last Glacial Maximum (LGM). Horizontal and vertical recession from this maximum is recorded by a series of ice-shelf moraines constructed against these adjacent land surfaces. Sediment on the contemporary ice-shelf surface is a mixture of relict and active debris-transport processes.

Spatially extensive areas of debris on the ice-shelf surface represent the debris load of a grounded ice-sheet/ice-shelf system at the LGM, now effectively stranded on the ice-shelf surface in an area of low contemporary ice-shelf velocity. The low surface velocities, coupled with high surface ablation rates, mean that this debris was not carried to the ice-shelf edge and lost to calving processes. This represents a process by which ice shelves can maintain and sequester a debris load for thousands of years, potentially providing a mechanism by which ice shelves could accumulate sufficient debris to contribute to Heinrich events (Hulbe and others, 2004). Under contemporary conditions, this debris is locally redistributed by surface ablation (creating an icecored landscape characterized by large debris-rich mounds and cycles of ice-core degradation and freezing), ice-shelf flow (forming medial moraines) and meltwater streams (locally reworking supraglacial material and redistributing it across the ice-shelf surface).

Angular supraglacial debris, representing point-sourced rockfall onto the ice-shelf surface and passive supraglacial transport, is generally absent, and most of the surface debris displays evidence of active transport, in the form of subtle basal glacial or fluvial modification. Once released from the ice shelf, either by transport to the ice-shelf edge or by catastrophic break-up of the ice shelf, this debris is a potential source of coarse-grained sediment to the sea floor. Episodic release of this coarse-grained debris by ice shelves could therefore be misinterpreted in the geological record as evidence for palaeo-grounding-line advances, since coarse-grained sedimentation is most commonly associated with sedimentary processes at, or close to, the grounding line of Antarctic glaciers and ice shelves (Anderson and others, 1991; Domack and others, 1999; Evans and Pudsey, 2002). Our conceptual model provides a framework for supraglacial ice-shelf debris transport that can be tested against the sedimentary record on the Antarctic continental shelf, in other contemporary ice-shelf settings and in the geological record.

\section{Contemporary ice-dynamics, mass-balance and debris-entrainment mechanisms}

Our data and observations from this area of the McMurdo Ice Shelf indicate that in view of its relatively thin ice, high ablation rates and slow velocities, the area is potentially unstable. In particular, low velocities in the ablation area may indicate that basal freezing is an important input to the mass balance of this part of the ice shelf. The spatial variability of basal freezing may be the controlling factor in mass balance and ice motion in this area, particularly around very slowly moving areas such as Bratina Island. This is in contrast to the dominance of surface inputs and outputs found in a typical glacial mass-balance system. The $\delta^{18} \mathrm{O}$ data collected on the ice surface in the ablation area of the ice shelf indicate that the ice here is of marine origin (Kellogg and others, 1990), whilst near the northern edge of the ice shelf, ice cores show the shelf to be composed of fresh-water ice, formed from surface meltwater refreezing at the base of the ice shelf after it has drained down tide cracks (Gow and others, 1965).

These observations suggest that the ice shelf is sustained by freezing-on of marine and fresh water under the ice shelf. Basal ice formation has been observed at other ice shelves. The bottommost $6 \mathrm{~m}$ of a $416 \mathrm{~m}$ core from the Ross Ice Shelf (Zotikov and others, 1980), $45 \mathrm{~m}$ of a $315 \mathrm{~m}$ core from the Amery Ice Shelf (Morgan, 1972), and $62 \mathrm{~m}$ of a $215 \mathrm{~m}$ core from site B13 and $167 \mathrm{~m}$ of a $320 \mathrm{~m}$ core from site B15 on the Filchner-Ronne Ice Shelf (Oerter and others, 1992, 1994) are comprised of ice formed by basal freezing. Model calculations indicate that, in favourable conditions, up to $4 \mathrm{~m}$ of marine ice can form per year at the base of ice shelves (Smedsrud and Jenkins, 2004).

Sub-ice-shelf accumulation is balanced by ablation on the ice-shelf surface, which leads to the concentration of debris on its upper surface. Our observation that surface debris sits directly on the ice shelf and has no connection to underlying ice structures confirms this. Measurements of basal melting and freezing rates in this area are essential to ascertain the potential future stability of this part of the McMurdo Ice Shelf.

The BIMM may represent debris accumulated along a former flow-unit boundary which, under the contemporary flow regime, is now being redistributed across the ice-shelf surface by meltwater streams and ponds. Large areas of surface debris in the Swirls area between Brown Peninsula and Black Island (Fig. 1) have no source area on the ice shelf and must represent deformation of pre-existing surface 
material that cannot be related to contemporary flow. On the basis of ${ }^{14} \mathrm{C}$ dates, Kellogg and others (1990) suggested that this debris was deposited by a grounded ice sheet that flowed westward into the area during the LGM. They argued that since the debris continues onto land, this part of the ice shelf has been stagnant since the LGM. Kellogg and others (1990) therefore suggested that the ice shelf in the Swirls area has only very recently become ungrounded.

\section{Implications for models of ice-sheet/ice-shelf interactions in the Late Pleistocene and Holocene}

Our field data can be used to test the two existing models for ice-sheet/ice-shelf interactions in the Ross Sea-McMurdo Sound area in the Late Pleistocene and Holocene. The first of these hypotheses is that at the LGM the area was inundated by a grounded ice sheet that filled the entire Ross Sea embayment (Denton and others, 1989; Kellogg and others, 1990). In this model, ice flow was from east to west across McMurdo Sound. The second model also invokes grounded ice but suggests that three coexisting ice lobes flowed into the area (Wilson, 2000). These lobes were an expanded and grounded Koettlitz Glacier lobe, a Ross Ice Shelf lobe and a smaller medial lobe fed from grounded ice in the Ross Sea that flowed between Brown Peninsula and Black Island. Our interpretation of the debris left stranded on the ice-shelf surface in the Swirls area is most easily accommodated by the model of Wilson (2000), in which this debris represents the deformed remnants of a set of terminal moraines marking the extent of a tongue of ice that flowed between Brown Peninsula and Black Island. This suggests that the ice shelf has been a permanent feature through the Late Pleistocene and Holocene, although it is likely to have thinned during this time.

\section{CONCLUSIONS}

The McMurdo Ice Shelf is unusual amongst Antarctic ice shelves in that it has a large ablation area with high ablation rates and limited ice flux, which allows debris to concentrate on its surface. This surface debris provides valuable information on contemporary and previous debris-transport processes on the ice shelf. Particular concentrations of debris are present: (i) in a large medial moraine flowing northward from Black Island and (ii) on the ice-shelf surface around Bratina Island and in the Swirls area. The sediments on McMurdo Ice Shelf are from a mix of relict and contemporary debris-transport processes. For example, the BIMM is interpreted as a contemporary medial moraine formed between two individual flow units, in which some sediments show evidence of subglacial transport. Meltwater ponds and streams on the ice-shelf surface play an important role in recycling debris from this moraine. The debris in the Swirls area is demonstrably older and was probably brought into the area by a former ice tongue before becoming stranded on the ice-shelf surface in an area of low contemporary ice-shelf velocities. This represents a process by which ice shelves can maintain and sequester a debris load for thousands of years. These deposits are currently being reworked by surface ablation processes to create an ice-cored landscape characterized by large debris-rich mounds and cycles of ice-core degradation. The area of ice shelf around Bratina Island and Brown Peninsula is currently entraining modern faunal remains via anchor ice freezing to the bottom of the ice shelf.

\section{ACKNOWLEDGEMENTS}

This research was supported by Antarctica New Zealand and the University of Canterbury. N.F. Glasser acknowledges financial support from the TransAntarctic Association. B. Goodsell was supported by The Leverhulme Trust. We thank P. Clendon for access to weather station data at Bratina Island, M. Finnemore of Southern Geophysical Ltd for assistance with migration of the GPR data, and NASA for providing access to the ASTER data. H. Cave, A. Halsted, E. Patterson and L. Fearnley are thanked for their help in the field.

\section{REFERENCES}

Anderson, J.B., D.S. Kennedy, M.J. Smith and E.W. Domack. 1991. Sedimentary facies associated with Antarctica's floating ice masses. In Anderson, J.B. and G.M. Ashley, eds. Glacial marine sedimentation; paleoclimatic significance. Boulder, CO, Geological Society of America, 1-25. (GSA Special Paper 261.)

Benn, D.I. and C.K. Ballantyne. 1994. Reconstructing the transport history of glacigenic sediments: a new approach based on the co-variance of clast form indices. Sediment. Geol., 91(1-4), 215-227.

Bennett, M.R., M.J. Hambrey and D. Huddart. 1997. Modification of clast shape in high-Arctic glacial environments. J. Sediment. Res., 67(3), 550-559.

Bennett, M.R., M.J. Hambrey, D. Huddart N.F. Glasser and K.R. Crawford. 1999. The landform and sediment assemblage produced by a tidewater glacier surge in Kongsfjorden, Svalbard. Quat. Sci. Rev., 18, 1213-1246

Boulton, G.S. 1978. Boulder shapes and grain-size distributions of debris as indicators of transport paths through a glacier and till genesis. Sedimentology, 25(6), 773-799.

Bradshaw, M.A. 1990. Geological history. In Hatherton, T., ed. Antarctica: the Ross Sea Region. Wellington, DSIR Publishing.

Brady, H.T. 1978. Geological studies in southern Victoria Land, on Black Island, and on the McMurdo Ice Shelf. Antarct. J. U.S., 13(4), 13-14.

Bushell, V.C. 1970. Plate XIII: Terra Nova Bay-McMurdo Sound area. Folio 12. Antarctic Map Folio Series - Geologic Maps of Antarctica. New York, American Geographic Society.

De Angelis, H. and P. Skvarca. 2003. Glacier surge after ice shelf collapse. Science, 299(5612), 1560-1562.

Debenham, F. 1920. A new mode of transportation by ice: the raised marine muds of South Victoria Land (Antarctica). QJ Geol. Soc. London, 75(2), 51-76.

Debenham, F. 1961. A fish story from the Antarctic. The Geographical Magazine, 34(6), 360-368.

Debenham, F. 1965. The genesis of the McMurdo Ice Shelf, Antarctica. J. Glaciol., 5(42), 829-832.

Denton, G.H., J.G. Bockheim, S.C. Wilson and M. Stuiver. 1989. Late Wisconsin and Early Holocene glacial history, inner Ross embayment, Antarctica. Quat. Res., 31(2), 151-182.

Domack, E.W., E.K. Jacobson, S.S. Shipp and J.B. Anderson. 1999. Late Pleistocene-Holocene retreat of the West Antarctic icesheet system in the Ross Sea: Part 2 - sedimentologic and stratigraphic signature: geophysical results. GSA Bull., 111(10), $1517-1536$.

Evans, J. and C.J. Pudsey. 2002. Sedimentation associated with Antarctic Peninsula ice shelves: implications for palaeoenvironmental reconstructions of glacimarine sediments. J. Geol. Soc. London, 159(3), 233-237.

Evans, J. and C. Ó Cofaigh. 2003. Supraglacial debris along the front of the Larsen-A Ice Shelf, Antarctic Peninsula. Antarct. Sci., 15(4), 503-506.

Glasser, N.F., M.R. Bennett and D. Huddart. 1999. Distribution of glaciofluvial sediment within and on the surface of a high Arctic valley glacier: Marthabreen, Svalbard. Earth Surf. Process. Landforms, 24(4), 303-318. 
Gomez, B. and R.J. Small. 1985. Medial moraines of the Haut Glacier d'Arolla, Valais, Switzerland: debris supply and implications for moraine formation. J. Glaciol., 31(109), 303-307.

Gow, A.J., W.F. Weeks, G. Hendrickson and R. Rowland. 1965. New light on the mode of uplift of the fish and fossiliferous moraines of the McMurdo Ice Shelf, Antarctica. J. Glaciol., 5(42), 813-828.

Hambrey, M.J. and N.F. Glasser. 2003. Glacial sediments: processes, environments and facies. In Middleton, G.V., ed. Encyclopedia of sediments and sedimentary rocks. Dordrecht, Kluwer, 316-331.

Hart, C.P. 1990. Holocene megafauna in McMurdo Ice Shelf sediments - fossilization and implications for glacial processes. Antarct. J. U.S., 25(2), 11-14.

Hawes, I., R. Smith, C. Howard-Williams and A.-M. Schwarz. 1999. Environmental conditions during freezing, and response of microbial mats in ponds of the McMurdo Ice Shelf, Antarctica. Antarct. Sci., 11, 198-208.

Hayward, P.J. and P.D. Taylor. 1984. Fossil and recent Cheilostomata (Bryozoa) from the Ross Sea, Antarctica. J. Nat. Hist., 18, 71-94.

Hulbe, C.L., D.R. MacAyeal, G.H. Denton, J. Kleman and T.V. Lowell. 2004. Catastrophic ice shelf breakup as the source of Heinrich event icebergs. Paleoceanography, 19(1), PA1004. (10.1029/2003PA000890.)

Joughin, I. and L. Padman. 2003. Melting and freezing beneath Filchner-Ronne Ice Shelf, Antarctica. Geophys. Res. Lett., 30(9), 1477-1480.

Kellogg, D.E. and T.B. Kellogg. 1987. Diatoms of the McMurdo Ice Shelf, Antarctica: implications for sediment and biotic reworking. Palaeogeogr., Palaeoclimatol., Palaeoecol., 60(1-2), 77-96.

Kellogg, T.B., M. Stuiver, D.E. Kellogg and G.H. Denton. 1977. Marine microfossils on the McMurdo Ice Shelf. Antarct. J. U.S., 12(4), 82-83.

Kellogg, T.B., D.E. Kellogg and M. Stuiver. 1990. Late Quaternary history of the southwestern Ross Sea: evidence from debris bands on the McMurdo Ice Shelf, Antarctica. In Bentley, C.R., ed. Contributions to Antarctic research I. Washington, DC, American Geophysical Union, 25-56. (Antarctic Research Series 50.)

MacAyeal, D.R., T.A. Scambos, C.L. Hulbe and M.A. Fahnestock. 2003. Catastrophic ice-shelf break-up by an ice-shelf-fragmentcapsize mechanism. J. Glaciol., 49(164), 22-36.

Mercer, J.H. 1978. West Antarctic ice sheet and $\mathrm{CO}_{2}$ greenhouse effect: a threat of disaster. Nature, 271(5643), 321-325.

Moncrieff, A.C.M. 1989. Classification of poorly sorted sedimentary rocks. Sediment. Geol., 65(1-2), 191-194.

Morgan, V.I. 1972. Oxygen isotope evidence for bottom freezing on the Amery Ice Shelf. Nature, 238(5364), 393-394.

Narod, B.B. and G.K.C. Clarke. 1994. Miniature high-power impulse transmitter for radio-echo sounding. J. Glaciol., 40(134), 190-194.

Oerter, H. and 6 others. 1992. Evidence for basal marine ice in the Filchner-Ronne Ice Shelf. Nature, 358(6385), 399-401.
Oerter, H., H. Eicken, J. Kipfstuhl, H. Miller and W. Graf. 1994. Comparison between ice core B13 and B15. In Oerter, H., ed. Filchner-Ronne Ice Shelf Programme (FRISP). Report No. 7 (1994). Bremerhaven, Alfred Wegener Institute for Polar and Marine Research, 29-36.

Powers, M.C. 1953. A new roundness scale for sedimentary particles. J. Sediment. Petrol., 23(2), 117-119.

Pridmore, R.D., W.N. Vant and V.J. Cummings. 1995. Factors affecting the water clarity of ponds on the McMurdo Ice Shelf, Antarctica. Antarct. Sci., 7(2), 145-148.

Rack, W., C.S.M. Doake, H. Rott, A. Siegel and P. Skvarca. 2000. Interferometric analyzis of the deformation pattern of the northern Larsen Ice Shelf, Antarctic Peninsula, compared to field measurements and numerical modeling. Ann. Glaciol., 31, 205-210.

Rignot, E. and D.R. MacAyeal. 1998. Ice-shelf dynamics near the front of the Filchner-Ronne Ice Shelf, Antarctica, revealed by SAR interferometry. J. Glaciol., 44(147), 405-418.

Rott, H., W. Rack, T. Nagler and P. Skvarca. 1998. Climatically induced retreat and collapse of northern Larsen Ice Shelf, Antarctic Peninsula. Ann. Glaciol., 27, 86-92.

Scambos, T.A., C. Hulbe, M. Fahnestock and J. Bohlander. 2000. The link between climate warming and break-up of ice shelves in the Antarctic Peninsula. J. Glaciol., 46(154), 516-530.

Shepherd, A., D. Wingham, T. Payne and P. Skvarca. 2003. Larsen ice shelf has progressively thinned. Science, 302(5646), 856-859.

Smedsrud, L.H. and A. Jenkins. 2004. Frazil ice formation in an ice shelf water plume. J. Geophys. Res., 109(C3), C03025. (10.1029/2003JC001851.)

Speden, I.G. 1962. Fossiliferous Quaternary marine deposits in the McMurdo Sound region, Antarctica. NZJ. Geol. Geophys., 5(5), 746-777.

Sugden, D.E. and C.M. Clapperton. 1981. An ice-shelf moraine, George VI Sound, Antarctica. Ann. Glaciol., 2, 135-141.

Swithinbank, C.W.M., D.G. Darby and D.E. Wohlschlag. 1961. Faunal remains on an Antarctic ice shelf. Science, 133(3455), 764-766.

Vaughan, D.G. and C.S.M. Doake. 1996. Recent atmospheric warming and retreat of ice shelves on the Antarctic Peninsula. Nature, 379(6563), 328-331.

Williams, M.J.M., K. Grosfeld, R.C. Warner, R. Gerdes and J. Determann. 2001. Ocean circulation and ice-ocean interaction beneath the Amery Ice Shelf, Antarctica. J. Geophys. Res. 106(C10), 22,383-22,399.

Wilson, G.S. 2000. Glacial geology and origin of fossiliferouserratic-bearing moraines, southern McMurdo Sound, Antarctica - an alternative ice sheet hypothesis. In Paleobiology and paleoenvironments of Eocene rocks, McMurdo Sound, East Antarctica. Washington, DC, American Geophysical Union, 1937. (Antarctic Research Series 76.)

Zotikov, I.A., V.S. Zagorodnov and J.V. Raikovsky. 1980. Core drilling through the Ross Ice Shelf (Antarctica) confirmed basal freezing. Science, 207(4438), 1463-1465. 